\title{
An Examination of Seven Sociopolitical Factors and Their Connection with State Environmental Expenditures
}

\author{
Robert P. Blauvelt (Corresponding author) \\ GEI Consultants, 1 Greenwood Avenue, Suite 210, Montclair, New Jersey 07042, United \\ States of America
}

Tel: 973-873-7127Ｆax: 973-509-9625Ｅ-mail: rblauvelt@geiconsultants.com

Received: June 21, 2015 Accepted: August 3, 2015 Published: November 23, 2015

doi:10.5296/jee.v6i2.7865 URL: http://dx.doi.org/10.5296/jee.v6i2.7865

\begin{abstract}
State environmental agencies serve as first-responders during and after environmental disasters (man-made or natural), track and identify individuals and businesses that violate anti-pollution statutes, and function as scientific and data-gathering centers for policy makers. The robustness of a state environmental agency's budget also can be a measure of a state's environmental commitment. An understanding of the funding dynamics associated with establishing a state's environmental agency budget is a complex political ballet with often mysterious and competing forces influencing the financial choreography.

This paper analyzes possible political and cultural influences on budgetary outcomes in an attempt to identify those common, underlying, non-econometric factors that may drive or significantly contribute to state environmental agency funding. Those described here include, for 49 states (exclusive of Hawaii) between 2000 and 2009, total state expenditures, per capita income, educational attainment, agency staffing, environmental quality as measured through impaired waters, citizen ideology, and state agency performance. A Pearson's product moment correlation coefficient is used to compare state environmental expenditures to these seven data sets.

Those states showing the biggest change (positive or negative) in annual environmental agency budgets also have the strongest correlation (positive or negative) with the total number of independent variables. This relationship implies that changes to sociopolitical factors may sway or have an influence on state environmental agency funding. As the number of correlations increase, their effect on agency funding may become more pronounced. This
\end{abstract}


suggests a "critical mass" type relationship. Alternatively, as more sociopolitical factors combine to compel either increases or decreases in environmental agency funding, legislative priorities might be re-organized to accommodate that pressure with funding levels adjusted accordingly. The confluence of these special interests, either positively or negatively, may force environmental agency funding levels to overcome or shed local suppressive or masking effects (political scandals, policy distractions, etc.) to more closely reflect constituent demands and concerns.

Keywords: environmental expenditures, sociopolitical, correlation, state agency 


\section{Introduction}

State environmental agencies are one of the primary ways public health and quality of life is managed and protected within the United States. These regulatory departments and bureaus serve as first-responders during and after environmental disasters (man-made or natural), track and identify individuals and businesses that violate anti-pollution statutes, and function as scientific and data-gathering centers for policy makers. The robustness of a state environmental agencies budget also has been used as one of numerous surrogate measures of a state's environmental commitment or "greenness" (Patten, 1998; Newmark \& Witko, 2007; Kronisky \& Woods, 2012).

Funding available to these agencies determines program priorities and initiatives which can vary from inspecting hazardous waste storage facilities to keeping parks and waterways clear of litter. Governors and legislators have significant power to establish or set environmental agency funding levels. However, they do not get free reign. Policy-makers must operate within a framework of a watchful press, lobbying groups of varying strengths and effectiveness and, most importantly, one that respects the numerous federal programs over which the majority of states have assumed primacy (e.g., Clean Air Act, Clean Water Act). A complete understanding of the funding dynamics associated with setting a state's environmental agency budget is unique to each state. A single or even extensive set of metrics will not be able to capture the subtleties related to the complex political ballet within a state-house, budget committee, or chief executive's office. However, as with any constituent service program competing for scarce resources, there likely are central, underlying forces that will set the funding stage and influence the budgetary choreography.

An earlier paper (Blauvelt, 2014) examined the possible connections between seven econometric factors and state environmental agency budgets. Those included population, gross state product, pollution levels, health outcomes, and several other independent variables. In this paper the analysis is expanded to include political and cultural influences in lieu of those principally related to state econometrics. The objective is to identify common, underlying, non-econometric factors that may drive or significantly contribute to state environmental agency funding. Finding a universal set of state environmental agency budgetary precursors is improbable, but state programs are fundamentally driven by a common base line (federal programmatic requirements). While this baseline is modified at the state level by cultural attitudes and political leanings, the desirability of a clean environment, like public safety, access to health care, and quality education, is not in question. It is this more common, although not universal, subset of sociopolitical state environmental agency funding drivers that are being sought.

\section{Study Basis}

The role sociopolitical factors play in the establishment of funding levels for state environmental agencies has been evaluated by several researchers. Kronisky and Woods' 2012 analysis cautions researchers that measures of state environmental efforts (e.g., spending, ranking indices, or number of enforcement actions) are not equally meaningful and careful thought is necessary concerning variable choices. In Woods' 2005 analysis of factors 
determining whether a state will assume responsibility for the implementation of federal environmental statues, the author finds that a nuanced view of political and economic factors is necessary to fully understand the dynamics of intergovernmental and environmental policy. Heckmans's 2012 discussion of government capacity with regards to citizen ideology and air pollution emphasizes the importance of performance metrics and affirms that numerous factors interact in characterizing governmental agency effectiveness on environmental matters.

Public health indicators are sometimes cited as environmental policy drivers. When so used, they usually serve as non-specific or surrogate measures of overall state environmental quality. These types of public health markers can include mortality or life expectancy by state (Woods et al., 2008), asthma rates (To et al., 2013), and rate of low birth weight babies (Ahern et al., 2011; Yorifuj et al., 2015). However, public health outcomes as a measure of environmental policy may be either too relationally confounding or transitory to serve as directly correlative measures of long-term environmental policy effects.

More direct environmental quality measures such as air pollution (Heckman, 2012), extent of impaired waters (Reimer et al., 2013), and pollutant emission reported under the Toxic Release Inventory (Gerde \& Logsdon, 2001; Delmas \& Blass, 2010) have been used as measures of "problem severity". The underlying hypothesis being that those businesses or states with significant environmental quality problems will, under pressure from stakeholders, tend to be more assertive in addressing those issues (Ellison \& Newmark 2010; Reimer et al., 2013). Some studies support this correlation (e.g., Patten, 1998; Bae, 2012), while data from others suggest different results (Freedman \& Patten, 2004; Connors et al., 2013).

Income levels, manufacturing activity (as measured by gross state product), and state environmental expenditures are selected as measures used in the evaluation of either agency performance or legislative intent in papers by Hays et al., 1996; Koven \& Mausolff, 2002; and Woods et al., 2008. Non-economic factors also have been used regularly to assess the presence or strength of relationships between state environmental commitment and constituent characteristics. Educational attainment (Koven \& Mausolff, 2002; Konisky, 2011; Chamberlain, 2013), advocacy group activity (Hays et al., 1996) and moral or cultural beliefs (Heckman, 2012; Olive et al., 2012) have been shown to be correlated, either positively or negatively, with state environmental policy development and outcomes.

An extensive body of work exists that describes the relationship between political culture and environmental policy; although findings are far from definitive. Studies such as Hays et al. 1996; Koven \& Mausolff, 2002; and Heckman, 2012 tend to confirm the intuitive belief that a liberal state citizenry (i.e., politically Democratic or left-leaning) will be strongly committed to environmental policies. However, research efforts by Sharp \& Haider-Markel, 2008; Olive et al., 2012; Flavin, 2012; and Chamberlain, 2013 do not show such a clear correlation; citing other factors such as activity by special interest groups, constituent wealth (income), and moral beliefs as playing a more crucial or dominant role in state environmental policy. 


\section{Dependent Variable}

This paper examines a combination of sociopolitical factors to identify those that may be influential in driving state environmental expenditures. Non-capital environmental expenditures between 2000 and 2009, adjusted to 2010 dollars, were chosen as the dependent variable. These expenditures include services and costs related to the regulation of natural resources, air quality, water quality, sanitary engineering, and other environmental activities. They exclude capital or "one-off" environmental projects such as waste water treatment plant construction or water supply/management projects. Environmental spending data is readily accessible and easily comparable across jurisdictions and appears to be reactive or sensitive to the budgetary preferences of legislative bodies which, presumably, are not insulated from the constituents they purport to serve.

Data sets for 49 states, exclusive of Hawaii because of its unique ecological and economic setting, were obtained from U.S. Census Bureau and are available at http://www.census.gov/govs/local. Using data from across the country over ten-years lessens the chance that the associations observed have been caused by a short-term set of circumstance or one-time political event (e.g., environmental calamity or upset election).

Between 2000 and 2009 state funding for environmental agencies remained essentially flat, with an average per year increase across the 49 states of only 0.6 percent. Twenty-one states inflicted annual budget decreases on their environmental agencies ranging from -5.8 percent for Illinois to -0.1 percent for Alaska. Twenty-seven states increased environmental agency funding; albeit at very modest rates with 17 of the 27 states experiencing annual budget increases of less than two percent. Eleven lucky states enjoyed annual budget increases of three percent or more with the grand prize going to North Dakota's Environmental Protection Agency that received a whopping (average) 9.3 percent increase every year over this ten year time span (2000-2009).

\section{Independent Variables}

Seven data sets were selected as independent variables; those possibly explaining or accounting for a state's environmental spending choices. These include, for the years 2000 through 2009, the following:

Total state expenditures. These are payments (i.e., total state spending normalized to 2010 dollars) by a government and its agencies, net of correcting transactions and recoveries or refunds, and excluding government-operated enterprises (e.g., lotteries), utilities, and public trust (pension) funds.

Per Capita Income. This data set represents the average (monetary) income received annually as computed for every man, woman, and child residing in a given state between 2000 and 2009 , adjusted to 2010 dollars. It is calculated by dividing the total income of all people 15 years old and over in the state by the total population of that state. Income is not considered for people under 15 years old. Income does include amounts reported separately for wages or salaries; net self-employment income; interest, dividends, or net rental or royalty income, or income from estates and trusts; as well as government pension and welfare programs. 
Educational Attainment. Measured in 2000 and 2005 through 2009 as a percent of the state's population age 25 years old and older that have attained at least a Bachelor's degree. The principal sources of data are the decennial census of the population as well as ongoing Current Population Surveys conducted by the U.S. Census Bureau. Data are supplemented with information taken from reports by administrators of educational institutions and through state and local agencies having jurisdiction over education.

Environmental Agency Staff. These data have been extracted from the U.S. Census Bureau's Annual Survey of Public Employment \& Payroll for 2000 through 2009. Employment estimates are for full-time equivalent (FTE) employees. The annual survey collects employment data broken out by functional category or type of job. This data set includes state government environmental agency employment between 2000 and 2009 for three categories: sewage, solid waste management, and natural resources. It does not include personnel assigned to the parks and recreation category.

Impaired Waters. The goal of the Clean Water Act (CWA) is "...to restore and maintain the chemical, physical, and biological integrity of the Nation's waters..." (33 U.S.C §1251(a)). Under section 303(d) of the CWA, states are required to develop lists of impaired waters. These are waters for which technology-based regulations and other required controls are not stringent enough to meet the water quality standards set by the states. The law requires that states create priority rankings for waters on the list and develop Total Maximum Daily Loads (TMDLs) for these waters. A TMDL is a calculation of the maximum amount of a pollutant that a water body can receive and still safely meet water quality standards. This data set (list of TMDLs by state by year) is reported by the states to EPA under Section 305(b) and 303(d) of the Clean Water Act. This report lists the number of TMDLs approved by EPA and serves as an indication of surface water quality conditions within a particular state.

Citizen and Government Ideology. Annual measures of state government ideology (liberal vs. conservative) as developed by Berry et al., 1998 and 2010. The measures are based on the revised 1960-2010 citizen ideology series that include roll call voting scores of state congressional delegations, the outcomes of congressional elections, the partisan divisions (Republican vs. Democratic) of state legislatures, the party of the governor, and various assumptions regarding voters and state political elites. These measures are combined into an additive scale (zero through 100) with the higher scores indicating more liberal political leanings.

Performance. Since 1998 the Pew Center on the States in cooperation with a number of academic institutions has conducted the Government Performance Project or GPP (Barrett \& Greene, 2008). The project systematically identifies how well states manage employees, budgets, and information in addition to ensuring that infrastructure (roads, bridges, etc.) is adequate and continues to serve constituents. The intent of the GPP is to measure how well states' policy decisions and practices actually deliver their intended outcomes. Results of GPP rankings, which are presented as letter grades (A, B, C, etc.) for 2000, 2001, 2005, and 2008, have been operationalized using a numerical variable ranging from 5.5 (A) through 4 (B) to 1 (D) to indicate the state's associated performance score. 
Establishing a causative relationship between the independent variables and state environmental agency funding is not a realistic or achievable study objective; especially given the linear nature of the statistical analysis employed and the multi-dimensional nature of the governmental budgeting process. However, confirming possible connections between individual or sets of state sociopolitical factors and environmental agency funding may allow heuristic or even simple predictive patterns to be identified.

\section{Comparison Methodology}

A Pearson's product moment correlation coefficient was used to compare environmental expenditures (EE) for each state with the seven data sets. A Pearson's product moment (r) is a dimensionless index that ranges from -1 to 1 inclusive and reflects the extent of a linear relationship between two data sets. For those correlations observed at -0.7 or 7 (strong correlations) and higher, two-tailed significance testing was done using a critical value of 2.306 at $\alpha=0.05$ with eight degrees of freedom. Table 1 summarizes calculated correlation coefficients for the 49 states evaluated. Also included on Table 1 is a list of more weakly correlated relationships (-0.6 and 0.6). These weaker correlations suggest a less robust, but perhaps still meaningful relationship between $\mathrm{EE}$ and the independent variables.

Table 1. Summary of Data Set Correlations with Environmental Expenditures

\begin{tabular}{|c|c|c|c|c|c|c|c|}
\hline \multirow[b]{2}{*}{ State } & \multicolumn{7}{|c|}{ Independent Variables } \\
\hline & $\begin{array}{l}\text { State } \\
\text { Expenditures }\end{array}$ & $\begin{array}{l}\text { Full Time } \\
\text { Equivalents }\end{array}$ & $\begin{array}{l}\text { Per } \\
\text { Capita } \\
\text { Income }\end{array}$ & $\begin{array}{l}\text { Educational } \\
\text { Attainment }\end{array}$ & $\begin{array}{l}\text { Citizen \& } \\
\text { Government } \\
\text { Ideology }\end{array}$ & Performance & $\begin{array}{l}\text { Impaired } \\
\text { Waters }\end{array}$ \\
\hline Alabama & 0.6 & --- & 0.7 & 0.8 & --- & 0.9 & --- \\
\hline Alaska & --- & --- & --- & -0.6 & --- & 0.9 & --- \\
\hline Arizona & 0.7 & 0.8 & 0.9 & 0.7 & 0.9 & 1.0 & --- \\
\hline Arkansas & -0.8 & --- & -0.9 & -1.0 & -0.7 & -0.6 & --- \\
\hline California & 1.0 & --- & --- & 0.9 & -0.8 & --- & 0.7 \\
\hline Colorado & 1.0 & --- & --- & --- & 0.6 & --- & 0.1 \\
\hline Connecticut & --- & -0.6 & -0.7 & -0.6 & -0.6 & --- & --- \\
\hline Delaware & 0.8 & --- & 0.8 & --- & --- & 0.6 & 0.9 \\
\hline Florida & --- & --- & --- & --- & --- & --- & --- \\
\hline Georgia & -0.8 & 0.7 & --- & 1.0 & 0.8 & -0.9 & --- \\
\hline Idaho & -0.6 & --- & --- & --- & --- & 0.8 & --- \\
\hline Illinois & -0.7 & 0.8 & -0.8 & -1.0 & -0.7 & 0.9 & --- \\
\hline Indiana & -0.6 & --- & --- & --- & --- & --- & --- \\
\hline Iowa & --- & 0.8 & --- & --- & --- & --- & -0.6 \\
\hline Kansas & --- & --- & --- & --- & --- & --- & --- \\
\hline Kentucky & -0.6 & 0.9 & --- & --- & -0.8 & 0.8 & -0.8 \\
\hline Louisiana & 0.8 & --- & 0.6 & 0.6 & --- & 0.8 & --- \\
\hline Maine & --- & --- & --- & --- & 0.7 & --- & --- \\
\hline Maryland & --- & --- & --- & --- & 0.8 & --- & --- \\
\hline Massachusetts & --- & 0.8 & --- & -0.8 & --- & 0.6 & --- \\
\hline Michigan & --- & 0.8 & 0.7 & -1.0 & -0.7 & 0.7 & --- \\
\hline Minnesota & -0.7 & --- & $\begin{array}{l}-0.9 \\
\end{array}$ & -0.9 & --- & --- & -0.6 \\
\hline Mississippi & --- & --- & ---- & --- & --- & ---- & --- \\
\hline Missouri & --- & --- & --- & --- & --- & 0.9 & --- \\
\hline Montana & --- & --- & --- & --- & --- & --- & --- \\
\hline Nebraska & 0.6 & --- & --- & --- & --- & --- & --- \\
\hline
\end{tabular}




\begin{tabular}{|c|c|c|c|c|c|c|c|}
\hline \multirow[b]{2}{*}{ State } & \multicolumn{7}{|c|}{ Independent Variables } \\
\hline & $\begin{array}{l}\text { State } \\
\text { Expenditures }\end{array}$ & $\begin{array}{l}\text { Full Time } \\
\text { Equivalents }\end{array}$ & $\begin{array}{l}\text { Per } \\
\text { Capita } \\
\text { Income }\end{array}$ & $\begin{array}{l}\text { Educational } \\
\text { Attainment }\end{array}$ & $\begin{array}{l}\text { Citizen \& } \\
\text { Government } \\
\text { Ideology }\end{array}$ & Performance & $\begin{array}{l}\text { Impaired } \\
\text { Waters }\end{array}$ \\
\hline Nevada & 0.7 & --- & 0.6 & --- & --- & 0.9 & --- \\
\hline New Hampshire & 0.8 & --- & --- & --- & --- & --- & --- \\
\hline New Jersey & $\overline{---}$ & --- & ---- & ---- & --- & ---- & --- \\
\hline New Mexico & 1.0 & -0.8 & 0.9 & 0.8 & 0.7 & 0.8 & --- \\
\hline New York & -0.6 & --- & -0.7 & -0.7 & $\begin{array}{l}-0.8 \\
\end{array}$ & -1.0 & --- \\
\hline North Carolina & --- & --- & $\begin{array}{l}-0.8 \\
\end{array}$ & --- & --- & 1.0 & --- \\
\hline North Dakota & 0.8 & --- & 0.9 & 0.9 & 0.7 & --- & --- \\
\hline Ohio & 0.8 & -0.6 & 0.6 & 0.7 & --- & --- & --- \\
\hline Oklahoma & --- & --- & --- & --- & --- & --- & --- \\
\hline Oregon & 0.7 & -0.6 & --- & 0.8 & --- & -0.7 & --- \\
\hline Pennsylvania & -0.9 & --- & -0.8 & -1.0 & -0.8 & -0.6 & --- \\
\hline Rhode Island & --- & 0.7 & --- & -0.7 & --- & 0.9 & --- \\
\hline South Carolina & --- & 0.9 & --- & -0.6 & 0.8 & --- & -0.6 \\
\hline South Dakota & 0.9 & 0.8 & 0.8 & 1.0 & --- & --- & --- \\
\hline Tennessee & 0.6 & 0.7 & --- & 0.8 & --- & --- & --- \\
\hline Texas & --- & --- & ---- & -0.7 & --- & -0.7 & $-\overline{--}$ \\
\hline Utah & --- & -0.6 & -0.6 & --- & --- & --- & --- \\
\hline Vermont & --- & -0.6 & -0.9 & --- & --- & --- & --- \\
\hline Virginia & 0.9 & --- & -0.7 & -0.9 & -0.7 & --- & --- \\
\hline Washington & --- & --- & --- & --- & --- & --- & --- \\
\hline West Virginia & -0.6 & -0.9 & -0.8 & -0.9 & -0.6 & --- & --- \\
\hline Wisconsin & --- & -0.7 & --- & 0.9 & --- & --- & --- \\
\hline Wyoming & 0.9 & 0.9 & 0.7 & 0.9 & 0.9 & 0.6 & 0.6 \\
\hline $\begin{array}{l}\text { TOTAL STRONG } \\
\text { CORRELATIONS }\end{array}$ & 18 & 15 & 17 & 23 & 16 & 17 & 3 \\
\hline $\begin{array}{l}\text { TOTAL WEAK } \\
\text { CORRELATIONS }\end{array}$ & 8 & 4 & 5 & 4 & 3 & 5 & 4 \\
\hline $\begin{array}{l}\text { TOTAL } \\
\text { CORRELATIONS }\end{array}$ & 26 & 19 & 22 & 27 & 19 & 22 & 7 \\
\hline
\end{tabular}

Twenty-two states (45 percent of the study group) had less than two or even no correlations with any of the data sets. This may indicate that other, state-specific factors were driving the budgetary processes that established or set the level of environmental expenditure funding. What those driving forces are would need to be examined on a case-by-case basis. One reason for this, as suggested by Willoughby, 2008 and Choi \& Coffey, 2011, is that high priority state-wide concerns can overwhelm or mask usual budgeting protocols and drivers. Examples might include long-term disaster recovery efforts in Florida after Hurricanes Andrew (1992) and Katrina (2005) or attempts at property tax reform and the other budgetary chaos related to proposed sales tax increases, including a shutdown in state government, in New Jersey between 2002 and 2006. These 22 non-correlation states are not included for further evaluation.

For the remaining 27 states, Table 2 illustrates the total number of correlations (positive and negative) between the average annual percent change (by state) in environmental agency funding between 2000 and 2009 (Annual Change) and the independent variables. 


\section{Ml Macrothink}

Table 2. Comparison of Percent Change in EE Funding with Data Set Correlations

\begin{tabular}{|c|c|c|c|c|c|}
\hline State & $\begin{array}{l}\% \\
\text { Change } \\
(2000-09)\end{array}$ & $\begin{array}{l}\text { Annual } \\
\text { Change }\end{array}$ & $\begin{array}{l}\text { No. Positive } \\
\text { Correlations }\end{array}$ & $\begin{array}{l}\text { No. of Negative } \\
\text { Correlations }\end{array}$ & $\begin{array}{l}\text { Total } \\
\text { Correlations }\end{array}$ \\
\hline Illinois & -52.2 & -5.8 & 2.0 & 4.0 & 6 \\
\hline Michigan & -43.5 & -4.8 & 3.0 & 2.0 & 5 \\
\hline West Virginia & -40.4 & -4.5 & 0.0 & 5.0 & 5 \\
\hline Virginia & -36.6 & -4.1 & 1.0 & 3.0 & 4 \\
\hline Pennsylvania & -30.0 & -3.3 & 0.0 & 5.0 & 5 \\
\hline South Carolina & -26.3 & -2.9 & 2.0 & 2.0 & 4 \\
\hline Kentucky & -25.4 & -2.8 & 2.0 & 3.0 & 5 \\
\hline Rhode Island & -23.7 & -2.6 & 2.0 & 1.0 & 3 \\
\hline Minnesota & -15.3 & -1.7 & 0.0 & 4.0 & 4 \\
\hline Arkansas & -15.0 & -1.7 & 0.0 & 5.0 & 5 \\
\hline Georgia & -13.9 & -1.5 & 3.0 & 2.0 & 5 \\
\hline New York & -8.3 & -0.9 & 0.0 & 5.0 & 5 \\
\hline Connecticut & -7.1 & -0.8 & 0.0 & 4.0 & 4 \\
\hline Massachusetts & 10.5 & 1.2 & 2.0 & 1.0 & 3 \\
\hline Alabama & 12.9 & 1.4 & 4 & 0 & 4 \\
\hline Arizona & 15.0 & 1.7 & 6.0 & 0.0 & 6 \\
\hline Ohio & 15.3 & 1.7 & 3.0 & 1.0 & 4 \\
\hline Oregon & 19.5 & 2.2 & 2.0 & 2.0 & 4 \\
\hline Nevada & 23.5 & 2.6 & 3.0 & 0.0 & 3 \\
\hline Louisiana & 28.3 & 3.1 & 4.0 & 0.0 & 4 \\
\hline Tennessee & 35.1 & 3.9 & 3.0 & 0.0 & 3 \\
\hline South Dakota & 43.1 & 4.8 & 4.0 & 0.0 & 4 \\
\hline Delaware & 43.8 & 4.9 & 4.0 & 0.0 & 4 \\
\hline California & 46.0 & 5.1 & 3.0 & 1.0 & 4 \\
\hline New Mexico & 60.4 & 6.7 & 5.0 & 1.0 & 6 \\
\hline Wyoming & 67.0 & 7.4 & 7.0 & 0.0 & 7 \\
\hline North Dakota & 83.6 & 9.3 & 4.0 & 0.0 & 4 \\
\hline
\end{tabular}

A Pearson's analysis also was run on the Table 2 data with results indicating a meaningful correlation (0.7) between Annual Change and the total number of positive or negative correlations. As the total number of correlations of the independent variable data sets increased or decreased so did the percent change in environmental agency funding. Stated differently, the higher the rate of annual budget increases (or decreases), the more positive (or negative) correlations with independent variables were present.

For example, Illinois decreased funding for its state environmental agency by more than half between 2000 and 2009, an average annual decrease of slightly more than five percent. As might be expected, two-thirds of correlations noted between independent variables and the dependent variable (environmental agency funding) proved to be negative. Conversely, North Dakota almost doubled its state environmental agency funding, increasing its budget about nine percent per year between 2000 and 2009. This probably was in response to the massive increase in shale gas exploration and development that had occurred and is ongoing in this 
state. Data set correlations during this time were all positive.

Twenty-one states correlated educational attainment strongly ( 0.7 positive or negative factor or more) with environmental expenditures. Another three established a weaker association (equal to a positive or negative of 0.6 ) between educational attainment and environmental expenditures. Twelve were negatively correlated, indicating that as education levels increased, expenditures on environmental funding decreased. This is counter to studies (Konisky, 2011 and Hirsh, 2014) where increasing levels of educational attainment were associated with greater constituent concern or appreciation of environmental issues which, in turn, should translate to greater environmental agency funding. Within those 12 negatively correlated states, eight (Arkansas, Connecticut, Illinois, Minnesota, New York, Pennsylvania, Virginia, and West Virginia) showed, where present, all or the majority of negative correlations with other independent variables (per capita income, citizen ideology, etc.).

The independent variable selected to serve as an indicator of environmental quality - Impaired Waters (the number of waterways not meeting water quality standards set by the states) - correlated strongly with environmental expenditures in only three states with weaker correlations in another three. This implies that the Impaired Waters metric is not a significant enough issue to drive environmental perceptions or stakeholder concerns at the state level.

Seventeen states correlated state expenditures strongly (positive or negative of 0.7 or more) with environmental expenditures. Five additional states had a weaker association with this dependent variable (equal to a positive or negative of 0.6). More than two-thirds of the correlated states (14) exhibited a positive association with environmental expenditures: as state expenditures rose so did agency funding. Negative correlations between environmental expenditures and state expenditures were present in eight states: Arkansas, Georgia, Illinois, Kentucky, Minnesota, New York, Pennsylvania, and West Virginia. Of those eight states, negative correlations were present between the dependent variable and all independent variables in five states: Arkansas, Minnesota, New York, Pennsylvania, and West Virginia.

Correlations between the number of FTE employees and environmental expenditures were found for 16 of the 27 states under consideration. Eleven of those correlations were positive; with environmental expenditures increasing as the number of agency FTE employees increased. Five states (Connecticut, New Mexico, Ohio, Oregon, and West Virginia had a negative correlation between FTE count and environmental expenditures; perhaps indicating allocation of agency resources to non-staffing priorities.

Per capita income correlations were positive for 11 states and negative for eight others. The eight negatively correlated states also demonstrated negative correlations between environmental expenditures and all or the majority of the other independent variables.

There were negative correlations between political ideology and environmental expenditures in ten states. As populist political views became less conservative (read Republican), the level of environmental expenditure funding increased. This tends to support the findings of DeNicola \& Subramanian, 2014 and McCright et al., 2014 who described similar associations. 
Nine states (Arizona, Colorado, Georgia, Maine, Maryland, New Mexico, North Dakota, South Carolina, and Wyoming) had positive correlations between political ideology and environmental expenditures. As the level of political conservatism increased, so did EE funding levels. Five of those states: Arizona, Maine, New Mexico, North Dakota, and Wyoming have significant components of their economies tied to environmental quality issues, be it tourism or shale gas extraction.

Seventeen states demonstrated a correlation between environmental expenditures and governmental performance. 12 were positive correlations implying that environmental, and probably other state agencies, were rewarded with increases in budgets for producing favorable policy outcomes. Five states (Arkansas, Georgia, New York, Oregon, and Pennsylvania) correlated Performance negatively with environmental expenditures; indicating that environmental issues were not significant drivers in setting state-wide policy or evaluating performance results.

\section{Discussion}

Of the seven sociopolitical factors serving as independent variables, previous studies would suggest that harmonized correlations with the dependent variable (environmental agency funding) should be present for five of them: state expenditures, FTE levels, per capita income, educational attainment, and bureaucratic performance. Environmental agency funding should change (increase or decrease) as the values for these independent variable increases or decrease.

Asici, 2013, Al Manum, 2014, and Leimbach et al., 2015 established links between economic growth, captured in this paper by state expenditures and per capita income, and environmental conditions. Similarly, Weston-Cox et al., 2012 and Li \& Elligers, 2014 connected state agency staffing levels (including non-environmental agencies) with funding. Education attainment has long been recognized as correlated to environmental awareness (Konisky, 2011; Koven \& Mausolff, 2002; and Chamberlain, 2013) and so, by extension, to the robustness of state environmental agency funding. The independent variable Performance, a measure of overall state bureaucratic effectiveness, is based largely on infrastructure and financial management (Barrett \& Greene, 2008). The Performance metric does not include a specific environmental component, but it serves as a reasonable, overall measure of how well policy outcomes (including environmental outcomes) are achieved within the larger framework of state governance. Performance should be tied closely (and positively) to agency funding.

This type of harmonized relationship was evident in 13 states. Seven states (Alabama, Arizona, Delaware, Louisiana, North Dakota, South Dakota, and Wyoming) demonstrated positive correlations between these five independent variables (educational attainment, state expenditures, FTEs, per capita income and government performance) and environmental expenditures. In another six (Arkansas, Connecticut, Minnesota, New York, Pennsylvania, and West Virginia), the relationship was negative; as levels of these five independent variables dropped, so did EE funding. 
The source or cause of this less than consistent correlation between EE and these five factors in the remaining 14 states may reside in the relationship between the independent variable data sets and the amount or extent of annual changes in environmental expenditures. Table 3 summarizes correlation findings between the total number of data set correlations by state and the annual percent change in environmental expenditures.

Table 3. Correlation Coefficients Compared to Percent Change in Environmental Agency Expenditures

\begin{tabular}{|l|l|}
\hline Independent Variable Correlations & Percent Change in EE \\
\hline Number of Positive Correlations & 0.7 \\
\hline Number of Negative Correlations & -0.7 \\
\hline
\end{tabular}

Those states showing the biggest change (positive or negative) in annual EE budget also show the strongest association (positive or negative) with the total number of correlations among the independent variables. From Table 2, as the annual percent change in EE increases (or decreases), so do the number of correlations with the independent variables. Changes to the five above mentioned sociopolitical factors (educational attainment, state expenditures, FTEs, per capita income and government performance) may sway or have an influence on EE funding patterns. As the number of correlations with environmental expenditures increase, their effect on EE funding may become more pronounced. This suggests a "critical mass" relationship. As more sociopolitical factors combine to compel either increases or decreases in environmental agency funding, legislative priorities are re-organized to accommodate that pressure and EE are adjusted accordingly. The confluences of these special interests, either positively or negatively, forces EE funding levels to overcome or shed local suppressive or masking effects (political scandals, policy distractions, etc.) to more closely reflect constituent demands and concerns.

These types of cross-sectional dynamics are better understood and more characterized (quantified) in other areas of public administration and spending such as the arts (Noonan, 2015), health care (Leider et al., 2014), and education (Dar, 2012). A further understanding of the nature, extent, and degree of interconnection of each sociopolitical factors influence on EE funding is needed before predictive or policy uses can be conceived. This may be fertile ground for advanced quantitative analysis using network visualization tools.

\section{References}

Ahern, M., Mullett, M., MacKay, K., \& Hamilton, C. (2011). Residence in coal-mining areas and low-birth-weight outcomes. Maternal \& Child Health Journal, 15(7), 974-979. http://dx.doi.org/10.1007/s10995-009-0555-1.

Al Mamun, M., Sohag, K., Hannan Mia, M. A., Salah Uddin, G., \& Ozturk, I. (2014). Regional differences in the dynamic linkage between $\mathrm{CO} 2$ emissions, sectoral output and economic growth. Renewable and Sustainable Energy Reviews, 38, 1-11. http://dx.doi.org/10.1016/j.rser.2014.05.091

Aşıcı, A. A. (2013). Economic growth and its impact on environment: A panel data analysis. 
Ecological Indicators, 24, 324-333. http://dx.doi.org/10.1016/j.ecolind.2012.06.019.

Bae, H. (2012). Reducing environmental risks by information disclosure: Evidence in residential lead paint disclosure rule. Journal of Policy Analysis and Management, 31(2), 404-431. http://dx.doi.org/10.1002pam.21600.

Barrett, K., \& Greene, R. (2008). Measuring Performance: The state management report card for 2008. Governing, March, 24.

Berry, D., Rinquist, E. J., Fording, R. C., \& Russell L. H. (1998). Measuring citizen ideology in the American States, 1960-1993. American Journal of Political Science, 42(1), 327-348.

Berry, W. D., Fording, R. C., Rinquist, E. J., \& Hanson, et al. (2010). Measuring citizen and government ideology in the American States: a re-appraisal. State Politics and Policy Quarterly, 10(2), 117-35.

Blauvelt, R. P. (2014). State environmental expenditures and their correlation with seven econometric factors. Journal of Environment and Ecology, 5(2), 172. http://dx.doi.org/10.5296/jee.v5i2.6374.

Chamberlain, A. (2013). The (dis)connection between political culture and external efficacy. American Politics Research, 41(5), 761. http://dx.doi.org/10.1177/1532673X12473503.

Choi, S. O., \& Coffey, A. (2011). Flexible budgeting in the public sector: The impact of disasters, terrorist attacks and wars on government expenditures. Public Finance \& Management, 11(2), 118-137.

Connors, E., Johnston, H. H., \& Gao, L. S. (2013). The informational value of Toxic Release Inventory performance. Sustainability Accounting, Management \& Policy Journal, 4(1), 32-55. http://dx.doi.org/10.1108/SAMPJ-01-2011-0003.

Dar, L. (2012). The political dynamics of higher education policy. Journal of Higher Education, 83(6), 769-794.

Delmas, M., \& Blass, V. (2010). Measuring corporate environmental performance. Strategy \& the Environment, 19(4), 245-260. http://dx.doi.org/10.1002/bse.676

DeNicola, E., \& Subramaniam, P. R. (2014). Narrative review: Environmental attitudes and political partisanship. Public Health, 128, 404-409. http://dx.doi.org/10.1016 /j.puhe.2014.03.005.

Ellison, B. A., \& Newmark, A. J. (2010). Building the reservoir to nowhere: The role of agencies in advocacy coalitions. Policy Studies Journal, 38(4), 653-678. http://dx.doi.org/10.1111/j.1541-0072.2010.00378.x.

Flavin, P. (2012). Income inequality and policy representation in the American states. American Politics Research, 40(1), 29-59. http://dx.doi.org/ 10.1177/1532573X11416920

Freedman, M., \& Patten, D. M. (2004). Evidence on the pernicious effect of financial report environmental disclosure. Accounting Forum, 28(1), 27-41. http://dx.doi.org/10.1016/ 
J.accfor.2004.04.006

Gerde, V., W., \& Logsdon, J. M. (2001). Measuring environmental performance: Use of the Toxic Release Inventory (TRI) and other U.S. environmental databases. Business Strategy and the Environment, 10(5), 269-285. http://dx.doi.org/10.1002/bse.293

Hays, S. P., Esler, M., \& Hays, C. E. (1996). Environmental commitment among the states: Integrating alternative approaches to state environmental policy. The Journal of Federalism, $26(2), 41$.

Heckman, A. C. (2012). Desperately seeking management: Understanding management quality and its impact on government performance outcomes under the Clean Air Act. Journal of Public Administration Research \& Theory, 22(3), 473-496. http://dx.doi.org/ 10.1093/jopart/mur068

Hirsh, J. B. (2014). Environmental sustainability and national personality. Journal of Environmental Psychology, 38, 233-240. http://dx.doi.org/ 10.1016/j.jenvp.2014.02.005

Konisky, D. (2011). Public preferences for environmental policy responsibility. Publius: The Journal of Federalism, 41(1): 76-100. http://dx.doi.org/ 10.1093/publius/pjp044

Konisky, D. M., \& Woods, N. D. (2012). Measuring state environmental policy. Review of Policy Research, 29(4), 544-569. http://dx.doi.org/ 10.1111/j.1541-1338.2012.00570.x

Koven, S. G., \& Mausolff, C. (2002). The influence of political culture on state budgets: Another look at Elazar's formulation. American Review of Public Administration, 32(1), 66-77. http://dx.doi.org/10.1177/0275074002032001004

Leider, J., P., Resnick, B., Kass, N., Sellers, K., Young, J., \& Bernet, P., et al. (2014). Budget and priority setting criteria at state health agencies in times of austerity: A mixed-methods study. American Journal of Public Health, 104(6), 1092-1099. http://dx.doi.org/10.2105 /AJPH.2013.301732

Leimbach, M., Kriegler, E., Roming, N., \& Schwanitz, J. (2015). Future growth patterns of world regions - A GDP scenario approach. Global Environmental Change, 31(3), 1-11 http://dx.doi.org/10.1016/j.gloenvcha.2015.02.005

Li, J., \& Elligers, A. (2014). Impact of budget cuts to environmental health services at local health departments: Key findings. Journal of Environmental Health, 76(10), 38-40.

McCright, A. M., Xiao, C., \& Dunlap, R. E. (2014). Political polarization on support for government spending on environmental protection in the USA, 1974-2012. Social Science Research, 48, 251-260. http://dx.doi.org/10.1016/j.ssresearch.2014.06.008

Newmark, A. J., \& Witko, C. (2007). Pollution, politics, and preferences for environmental spending in the states. Review of Policy Research, 24(4), 291-308. http://dx.doi.org/10.1111/j.1541-1338.2007.00284.x

Noonan, D. S. (2015). Arts of the states in crisis - Revisiting determinants of state-level $\begin{array}{llll}\text { appropriations } & \text { arts } & \text { Poetics, } & 49,\end{array}$ 
http://dx.doi.org/10.1016/j.poetic.2015.02.002

Olive, A., Gunasekara, V., \& Raymond, L. (2012). Normative beliefs in state policy choice, Political Research Quarterly, 65(3), 642-655. http://dx.doi.org/10.1177/1065912911408110

Patten, D. M. (1998). The impact of EPA's TRI disclosure program on state environmental and natural resource expenditures. Journal of Accounting and Public Policy, 17, 367-382.

Reimer, A. P., Gramig, B. M., \& Prokopy, L. S. (2013). Farmers and conservation programs: Explaining differences in environmental quality incentives program applications between states. Journal of Soil and Water Conservation, 68(2), 110. http://dx.doi.org/110-119

Sharp, E. B., \& Haider-Markel, D. (2008). At the invitation of the court: Eminent domain reform in state legislatures in the wake of the Kelo decision, Publius: The Journal of Federalism, 38(3), 556-75. http://dx.doi.org/10.1093/publius/pjn006

To, T., Shen, S., Atenafu, E., G., Guan, J., McLimont, S., \& Stocks, B., et al. (2013). The air quality health index and asthma morbidity: A population-based study. Environmental Health Perspectives, 121(1), 46-52. http://dx.doi.org/10.1289/eph.1104846

Weston-Cox, P., Anderson, A., \& Humphrey Jr., C. P. (2012). The impact of the economic downturn on environmental health services and professionals in North Carolina. Journal of Environmental Health, 74(10), 16-20.

Willoughby, K. G. (2008). Budget management capacity of state governments: issues and challenges. Public Performance \& Management Review, 31(3), 431.

Woods, N. D. (2005). Primacy implementation of environmental policy in the U.S. states. Publius: The Journal of Federalism, 36(2), 259-276.

Woods, N. D., Konisky, D. M., \& O'M. Bowman, A. (2008). You get what you pay for: Environmental policy and public health. Publius: The Journal of Federalism, 39(1), 95-116. http://dx.doi.org/10.1093/publius/pjn024.

Yorifuji, T., Kashima, S., \& Doi, H. (2015). Outdoor air pollution and term low birth weight in Japan. Environment International, 74, 106-111. http://dx.doi.org/10.1016/ j.envint.2014.09.003

\section{Copyright Disclaimer}

Copyright for this article is retained by the author(s), with first publication rights granted to the journal.

This is an open-access article distributed under the terms and conditions of the Creative Commons Attribution license (http://creativecommons.org/licenses/by/3.0/). 